\title{
Caenorhabditis elegans as Model System in Pharmacology and Toxicology: Effects of Flavonoids on Redox-Sensitive Signalling Pathways and Ageing
}

\author{
Karoline Koch, Susannah Havermann, Christian Büchter, and Wim Wätjen \\ Institute of Agricultural and Nutritional Sciences, Martin-Luther-Universität Halle-Wittenberg, Weinbergweg 22 (Biozentrum), \\ 06120 Halle, Germany
}

Correspondence should be addressed to Wim Wätjen; wim.waetjen@landw.uni-halle.de

Received 31 August 2013; Accepted 30 October 2013; Published 30 April 2014

Academic Editors: A. Basu and A. Okada

Copyright (C) 2014 Karoline Koch et al. This is an open access article distributed under the Creative Commons Attribution License, which permits unrestricted use, distribution, and reproduction in any medium, provided the original work is properly cited.

\begin{abstract}
Flavonoids are secondary plant compounds that mediate diverse biological activities, for example, by scavenging free radicals and modulating intracellular signalling pathways. It has been shown in various studies that distinct flavonoid compounds enhance stress resistance and even prolong the life span of organisms. In the last years the model organism C. elegans has gained increasing importance in pharmacological and toxicological sciences due to the availability of various genetically modified nematode strains, the simplicity of modulating genes by RNAi, and the relatively short life span. Several studies have been performed demonstrating that secondary plant compounds influence ageing, stress resistance, and distinct signalling pathways in the nematode. Here we present an overview of the modulating effects of different flavonoids on oxidative stress, redox-sensitive signalling pathways, and life span in C. elegans introducing the usability of this model system for pharmacological and toxicological research.
\end{abstract}

\section{Flavonoids}

Flavonoids are polyphenolic compounds that occur ubiquitously in fruit, vegetables, grains, nuts, tea, and wine (reviewed by $[1,2])$. The basic structure of flavonoids consists of an O-heterocyclic ring (B) fused to an aromatic ring (C) with a third ring system (A) attached at $\mathrm{C} 2$ of the heterocyclic ring (=phenylbenzopyrones). Up to now, over 6000 flavonoids have been identified.

A high number of flavonoids have been shown to be potent antioxidants due to their ability to donate electrons and the stabilisation of oxidized flavonoid species (semiquinone radical). Moreover, flavonoids form complexes with redox-active heavy metal ions, for example, $\mathrm{Fe}^{2+}$ and $\mathrm{Cu}^{2+}$ that are involved in Fenton-like reactions [3]. The antioxidant potential of flavonoids has been believed to be mediated by their biological actions for a long time, but from today's point of view it is by no means clear that other mechanisms of action contribute to their overall effect and are even more important than the radical scavenging properties. Flavonoids possess a remarkable spectrum of biochemical and pharmacological activities affecting basic cell functions (reviewed by [4]).

For example, mitogen-activated protein kinases (MAPK), major regulators of cell growth, proliferation, differentiation, and death, were shown to be modulated by these plant compounds. Specific flavonoids were shown to inhibit extracellular signal-related kinase (ERK-1/2), c-Jun amino-terminal kinase (JNK1/2), and p38-MAP kinase in cancer cell lines and stimulated immune cells $[5,6]$. Several flavonoids were also found to inhibit the nuclear factor- $\kappa \mathrm{B}(\mathrm{NF}-\kappa \mathrm{B})$ signalling pathway which is involved in inflammatory, immune, and stress response as well as in apoptosis and proliferation by activation of $\mathrm{I} \kappa \mathrm{B}$-kinase or blocking NF- $\kappa \mathrm{B}-\mathrm{DNA}$ association $[7,8]$. Consequently, suppression of NF- $\kappa \mathrm{B}$ signalling by flavonoids resulted in the inhibition of proinflammatory enzymes like phospholipase $\mathrm{A}_{2}\left(\mathrm{PLA}_{2}\right)$, lipoxygenase (LOX), and cyclooxygenase (COX) which are important targets in pharmacological sciences [9]. Flavonoids and isoflavonoids were found to influence the NO production by modulating the gene and protein expression of nitric oxide synthase (NOS) isoforms. Hämäläinen et al. [10] showed that 
flavone, daidzein, genistein, isorhamnetin, kaempferol, and quercetin inhibited the mRNA and protein expression of the inducible NOS in lipopolysaccharide stimulated murine J774 macrophages which was associated with a decreased activation of NF- $\kappa$ B. Some of these compounds were also found to inhibit the activation of the signal transducer and activator of transcription 1 (STAT-1). On the other hand the green tea flavonoid epigallocatechin-3-gallate (EGCG) was shown to increase endothelial nitric oxide synthase (eNOS) activity in a PI3K/PKB-dependent manner leading to vasodilation of rat aortic rings with the potential to protect against cardiovascular diseases [11].

Several molecular targets are discussed to explain the cytotoxicity of some flavonoids, for example, inhibition of protein kinase C [12], phosphorylase kinase [13], AMP phosphodiesterase [14], DNA topoisomerases $[15,16]$, glutathione S-transferases [17] leading to, for example, disruptions in cell cycle followed by apoptotic or necrotic events. An induction of apoptosis by flavonoids was reported for example, by Wei et al. [18] and Richter et al. [19].

Further on, diverse mechanistic studies have reported that flavonoids directly interfere with cell cycle regulation. For example, gallated catechins were reported to induce cell cycle arrest due to the suppression of cyclin D, cyclin E, and cyclin-dependent kinases (CDK) 1 and 4 protein expression $[20,21]$.

Besides the influence on basic cell functions, flavonoids are considered to exert chemoprotective effects by a modulation of the arylhydrocarbon-receptor (antagonists or weak agonists) which mediates the toxicity of halogenated aromatic hydrocarbons and polycyclic aromatic hydrocarbons [22, 23].

Because of the broad activity spectrum of flavonoids in diverse cell signalling pathways these phytochemicals are discussed to be protective against several diseases like cancer, obesity and diabetes [24], rheumatoid arthritis [25], and inflammatory diseases [26]. In fact, consumption of a diet rich in flavonoids is associated with beneficial effects to human health. In a prospective cohort study it has been shown that flavonoid intake is negatively associated with the risk of mortality from coronary heart disease (reviewed by [27]). Associations between the dietary intake of flavonoids and the incidences of a variety of cancers have also been studied in numerous prospective and case-control studies. Significant associations were observed for the incidence of, for example, oral, gastrointestinal, colorectal, liver, ovarian, endometrial, prostate, and breast cancer (reviewed by [28]). Consumption of flavonoid rich food and beverages like wine, chocolate, and tea was associated with an improved cognitive performance in the elderly, too [29]. Noticeable, these phytochemicals are claimed to protect mainly against diseases that occur in an age-dependent manner and proceed chronically. In societies with an increasing proportion of elderly and consequently rising incidences of age-related diseases it is important to seek for substances that may be utilized for pharmaceutical purposes in terms of prevention. Moreover it is important to understand the molecular mechanisms of ageing in order to develop strategies for modulating ageingassociated physiological changes and degenerations leading to chronic diseases. Due to the possibility to manipulate cell signalling pathways by simple biotechnological methods, the model organism $C$. elegans offers promising possibilities for studying the influence of secondary plant compounds like flavonoids on the process of ageing.

\section{Modulation of Life Span of C. elegans by Flavonoids}

Distinct flavonoids (Table 1) and flavonoid-rich plant extracts (Table 2) have been shown to modulate life span of C. elegans. The chemical structure of the compounds are shown in Figure 1. The prominent flavonoid quercetin $(100$ to $200 \mu \mathrm{M})$ increases mean and median life span by about $6-18 \%$ and $19-$ $21 \%$, respectively [30-36]. Additionally, nematodes treated with quercetin showed a higher (5 to $18 \%$ ) maximum life span than controls $[30,36]$. Pietsch et al. [35] revealed that quercetin mediated life span extension in $C$. elegans was characterised by an inverted U-shaped dose-response curve.

Increasing hydroxylation on rings $\mathrm{A}$ and $\mathrm{B}$ of the basic flavonoid structure seems to be crucial for the longevity effect in the nematode. It has been shown that flavonoids from the flavonol type prolonged the mean life span of C. elegans according to their number of $\mathrm{OH}$ groups in the $\mathrm{B}$ ring in the following order: kaempferol < quercetin < myricetin [31-38]. Baicalein, containing an additional $\mathrm{OH}$ group in the $\mathrm{A}$ ring, showed the most powerful effects. This flavonoid $(100 \mu \mathrm{M})$ increased mean, median, and maximum life span by 45,57 , and $24 \%$ [39].

Methylated derivatives of quercetin were shown to increase the mean life span of worms: 4-O-methylated quercetin (tamarixetin) was more efficient in life span prolongation than a methylation at position 3 (isorhamnetin) [34]. Glucopyranosides of the flavonoid quercetin $3^{\prime}-\mathrm{O}-\beta$ D-glucopyranoside $\left(\mathrm{Q}^{\prime} \mathrm{G}\right)$ and quercetin $3-\mathrm{O}-\beta$-D-glucopyranoside- $(4 \rightarrow 1)$ - $\beta$-D-glucopyranoside $(\mathrm{Q} 3 \mathrm{M})$ increased the mean life span of $C$. elegans compared to the control. The effect was comparable with the life span prolongation of quercetin [33]. Icariin and icariside II, bioactive compounds of Herba epimedii, are structurally related to a $3^{\prime}-\mathrm{O}-$ methylkaempferol glycoside. These flavonoids were found to increase the mean life span of $C$. elegans to a higher extent compared to kaempferol (21\% versus $6 \%)[36,40]$.

Flavonoids with a flavan-3-ol structure also induced a prolongation of life span in the nematodes: Saul et al. [41] showed that catechin enhanced mean and median life span of C. elegans at concentrations from 100 to $800 \mu \mathrm{M}$ [41]. The most effective concentration $(200 \mu \mathrm{M})$ of the flavonoid increased mean and median life span by about 9 and $13 \%$. In contrast, Surco-Laos et al. [42] did not observe an effect of catechin on longevity. However, epicatechin [43] and its $3^{\prime}$-O- and $4^{\prime}$-O-methylated derivatives could significantly enhance mean and maximum life span of the worms, once more indicating the importance of methylation. Similar to the quercetin derivatives, $4^{\prime}$-O-methylation induced a higher life span extension than $3^{\prime}$-O-methylation [42]. EGCG caused a mean life span expansion at high concentrations $(100 \mu \mathrm{M}$ : $20 \%$ and $220 \mu \mathrm{M}: 14 \%)[43,44]$ while low concentrations (under $25 \mu \mathrm{M}$ ) of the flavonoid did not induce longevity effects in C. elegans. 
TABLE 1: Modulation of the mean, median, and maximum life span in C. elegans by flavonoids in different studies.

\begin{tabular}{|c|c|c|c|c|c|c|}
\hline Flavonoid & Concentration & Temperature & $\begin{array}{c}\text { Mean } \\
\text { life span } \\
(\%)\end{array}$ & $\begin{array}{c}\text { Median } \\
\text { life span } \\
(\%)\end{array}$ & $\begin{array}{l}\text { Maximum } \\
\text { life span } \\
(\%)\end{array}$ & References \\
\hline $3^{\prime}$-O-Methylepicatechin & $200 \mu \mathrm{M}$ & $20^{\circ} \mathrm{C}$ & 7 & 11 & 4 & Surco-Laos et al., 2012 [42] \\
\hline $4^{\prime}$-O-Methylepicatechin & $200 \mu \mathrm{M}$ & $20^{\circ} \mathrm{C}$ & 13 & 11 & 10 & Surco-Laos et al., 2012 [42] \\
\hline $\begin{array}{l}\text { 3-O-Methyl quercetin } \\
\text { (isorhamnetin) }\end{array}$ & $200 \mu \mathrm{M}$ & $20^{\circ} \mathrm{C}$ & 16 & l & 16 & Surco-Laos et al., 2011 [34] \\
\hline $\begin{array}{l}\text { 4-O-Methyl quercetin } \\
\text { (tamarixetin) }\end{array}$ & $200 \mu \mathrm{M}$ & $20^{\circ} \mathrm{C}$ & 11 & l & l & Surco-Laos et al., 2011 [34] \\
\hline Baicalein & $100 \mu \mathrm{M}$ & $25^{\circ} \mathrm{C}$ & 45 & 57 & 14 & Havermann et al., 2013 [39] \\
\hline \multirow{8}{*}{ Catechin } & $100 \mu \mathrm{M}$ & $20^{\circ} \mathrm{C}$ & 8 & 11 & I & Saul et al., 2009 [41] \\
\hline & $200 \mu \mathrm{M}$ & $20^{\circ} \mathrm{C}$ & 9 & 13 & 1 & Saul et al., 2009 [41] \\
\hline & $200 \mu \mathrm{M}$ & $20^{\circ} \mathrm{C}$ & $\begin{array}{c}\text { No } \\
\text { difference }\end{array}$ & $\begin{array}{c}\text { No } \\
\text { difference }\end{array}$ & $\begin{array}{c}\text { No } \\
\text { difference }\end{array}$ & Surco-Laos et al., 2012 [42] \\
\hline & $200 \mu \mathrm{M}$ & $15^{\circ} \mathrm{C}$ & 15 & 14 & 1 & Saul et al., 2009 [41] \\
\hline & $200 \mu \mathrm{M}$ & $23^{\circ} \mathrm{C}$ & 11 & 9 & l & Saul et al., 2009 [41] \\
\hline & $300 \mu \mathrm{M}$ & $20^{\circ} \mathrm{C}$ & 6 & 10 & / & Saul et al., 2009 [41] \\
\hline & $400 \mu \mathrm{M}$ & $20^{\circ} \mathrm{C}$ & 8 & 11 & I & Saul et al., 2011 [7] \\
\hline & $800 \mu \mathrm{M}$ & $20^{\circ} \mathrm{C}$ & 6 & 10 & 1 & Saul et al., 2011 [7] \\
\hline \multirow[t]{2}{*}{ Epicatechin } & $200 \mu \mathrm{M}$ & $20^{\circ} \mathrm{C}$ & $\begin{array}{c}\text { No } \\
\text { difference }\end{array}$ & $\begin{array}{c}\text { No } \\
\text { difference }\end{array}$ & $\begin{array}{c}\text { No } \\
\text { difference }\end{array}$ & Surco-Laos et al., 2012 [42] \\
\hline & $100 \mu \mathrm{M}$ & $20^{\circ} \mathrm{C}$ & 15 & I & 11 & Bartholome et al., 2010 [43] \\
\hline \multirow{6}{*}{ Epigallocatechin gallate } & $100 \mu \mathrm{M}$ & $20^{\circ} \mathrm{C}$ & 20 & 1 & 13 & Bartholome et al., 2010 [43] \\
\hline & $220 \mu \mathrm{M}$ & $20^{\circ} \mathrm{C}$ & 10 & I & 1 & Abbas and Wink, 2009 [44] \\
\hline & $25 \mu \mathrm{M}$ & $22^{\circ} \mathrm{C}$ & $\begin{array}{c}\text { No } \\
\text { difference }\end{array}$ & l & $\begin{array}{c}\text { No } \\
\text { difference }\end{array}$ & Brown et al., 2006 [60] \\
\hline & $\begin{array}{l}0,1 \mu \mathrm{g} / \mathrm{mL} \\
(=0,2 \mu \mathrm{M})\end{array}$ & $20^{\circ} \mathrm{C}, 25^{\circ} \mathrm{C}$ & $\begin{array}{c}\text { No } \\
\text { difference }\end{array}$ & l & l & Zhang et al., 2009 [71] \\
\hline & $\begin{array}{c}1 \mu \mathrm{g} / \mathrm{mL} \\
(=2,2 \mu \mathrm{M})\end{array}$ & $20^{\circ} \mathrm{C}, 25^{\circ} \mathrm{C}$ & $\begin{array}{c}\text { No } \\
\text { difference }\end{array}$ & l & l & \\
\hline & $\begin{array}{l}10 \mu \mathrm{g} / \mathrm{mL} \\
(=22 \mu \mathrm{M})\end{array}$ & $20^{\circ} \mathrm{C}, 25^{\circ} \mathrm{C}$ & $\begin{array}{c}\text { No } \\
\text { difference }\end{array}$ & I & l & \\
\hline Icariin & $45 \mu \mathrm{M}$ & $25^{\circ} \mathrm{C}$ & 21 & I & I & Cai et al., 2011 [40] \\
\hline Icariside II & $20 \mu \mathrm{M}$ & $25^{\circ} \mathrm{C}$ & 22 & l & 1 & Cai et al., 2011 [40] \\
\hline $\begin{array}{l}\text { Isorhamnetin } \\
\text { (3-O-methyl quercetin) }\end{array}$ & $200 \mu \mathrm{M}$ & $20^{\circ} \mathrm{C}$ & 16 & l & 16 & Surco-Laos et al., 2011 [34] \\
\hline Kaempferol & $100 \mu \mathrm{M}$ & $20^{\circ} \mathrm{C}$ & 6 & 1 & 7 & Grünz et al., 2012 [36] \\
\hline \multirow{2}{*}{ Myricetin } & $100 \mu \mathrm{M}$ & $20^{\circ} \mathrm{C}$ & 18 & I & 22 & Grünz et al., 2012 [36] \\
\hline & $100 \mu \mathrm{M}$ & $25^{\circ} \mathrm{C}$ & 33 & & & Büchter et al., 2013 [38] \\
\hline \multirow{6}{*}{ Quercetin } & $50 \mu \mathrm{M}$ & $20^{\circ} \mathrm{C}$ & $\begin{array}{c}\text { No } \\
\text { difference }\end{array}$ & l & l & Pietsch et al., 2011 [35] \\
\hline & $\begin{array}{c}20 \mu \mathrm{g} / \mathrm{mL} \\
(=66,2 \mu \mathrm{M})\end{array}$ & $20^{\circ} \mathrm{C}$ & 14 & l & l & Xue et al., 2011 [33] \\
\hline & $100 \mu \mathrm{M}$ & $20^{\circ} \mathrm{C}$ & 6 & 1 & 18 & Grünz et al., 2012 [36] \\
\hline & $100 \mu \mathrm{M}$ & $20^{\circ} \mathrm{C}$ & 15 & 19 & 15 & Kampkötter et al., 2007 [37] \\
\hline & $100 \mu \mathrm{M}$ & $20^{\circ} \mathrm{C}$ & 10 & 1 & 1 & Saul et al., 2008 [31] \\
\hline & $100 \mu \mathrm{M}$ & $20^{\circ} \mathrm{C}$ & 11 & l & / & Pietsch et al., 2009 [32] \\
\hline
\end{tabular}


TABle 1: Continued.

\begin{tabular}{|c|c|c|c|c|c|c|}
\hline Flavonoid & Concentration & Temperature & $\begin{array}{c}\text { Mean } \\
\text { life span } \\
(\%)\end{array}$ & $\begin{array}{l}\text { Median } \\
\text { life span } \\
\quad(\%)\end{array}$ & $\begin{array}{l}\text { Maximum } \\
\text { life span } \\
(\%) \\
\end{array}$ & References \\
\hline & $200 \mu \mathrm{M}$ & $20^{\circ} \mathrm{C}$ & 18 & 21 & 1 & Pietsch et al., 2009 [32] \\
\hline & $200 \mu \mathrm{M}$ & $20^{\circ} \mathrm{C}$ & 10 & I & l & Saul et al., 2008 [31] \\
\hline & $200 \mu \mathrm{M}$ & $20^{\circ} \mathrm{C}$ & 11 & l & l & Surco-Laos et al., 2011 [34] \\
\hline & $250 \mu \mathrm{M}$ & $20^{\circ} \mathrm{C}$ & $\begin{array}{l}\text { About } \\
-7,00\end{array}$ & I & l & Pietsch et al., 2011 [35] \\
\hline $\begin{array}{l}\text { Quercetin } 3^{\prime}-\mathrm{O}-\beta \text {-D- } \\
\text { glucopyranoside }\end{array}$ & $\begin{array}{c}20 \mu \mathrm{g} / \mathrm{mL} \\
(=43,1 \mu \mathrm{M})\end{array}$ & $20^{\circ} \mathrm{C}$ & 12 & l & l & Xue et al., 2011 [33] \\
\hline $\begin{array}{l}\text { Quercetin } 3-\mathrm{O}-\beta \text {-D- } \\
\text { glucopyranoside- } \\
(4 \rightarrow 1)-\beta \text {-D- } \\
\text { glucopyranoside }\end{array}$ & $20 \mu \mathrm{g} / \mathrm{mL}$ & $20^{\circ} \mathrm{C}$ & 20 & I & l & Xue et al., 2011 [33] \\
\hline
\end{tabular}

TABLE 2: Modulation of the mean, median, and maximum life span of C. elegans by flavonoid rich plant extracts in different studies.

\begin{tabular}{lcccccc}
\hline Flavonoid rich extract & Concentration & Temperature & $\begin{array}{c}\text { Mean life } \\
\text { span (\%) }\end{array}$ & $\begin{array}{c}\text { Median life } \\
\text { span (\%) }\end{array}$ & $\begin{array}{c}\text { Maximum } \\
\text { life span (\%) }\end{array}$ & References \\
\hline Apple procyanidins & $65 \mu \mathrm{g} / \mathrm{mL}$ & & 12 & $/$ & Sunagawa et al., 2011 [47] \\
\hline $\begin{array}{l}\text { Ginkgo biloba extract } \\
\text { EGb } 761\end{array}$ & $100 \mu \mathrm{g} / \mathrm{mL}$ & $20^{\circ} \mathrm{C}$ & 10 & 16 & 17 & Kampkötter et al., 2007 [48] \\
\hline $\begin{array}{l}\text { Polyphenol-enriched } \\
\text { cocoa powder }\end{array}$ & $4 \mathrm{mg} / \mathrm{mL}$ & $20^{\circ} \mathrm{C}$ & 17 & $/$ & Martorell et al., 2011 [46] \\
\hline $\begin{array}{l}\text { Proanthocyanidins- } \\
\text { enriched extract from } \\
\text { blueberries }\end{array}$ & $200 \mu \mathrm{g} / \mathrm{mL}$ & $25^{\circ} \mathrm{C}$ & $\begin{array}{c}14,4 \\
f e m-1(h c 17)\end{array}$ & $/$ & Wilson et al., 2006 [45] \\
\hline
\end{tabular}

Next to the single compound, flavonoid-rich plant extracts were studied in regard to their life span prolonging properties (Table 2). In this context, procyanidins from cocoa apple and blueberry extracts were shown to enhance the mean life span by 12 to $17 \%$ in the nematode [45-47]. The Gingko biloba extract EGb 761 being rich in flavan-3-ol glycosides increased mean, median, and maximum life span of the nematode by 10,16 , and $17 \%$ [48].

\section{Influence of Flavonoids on the Oxidative Stress Level in C. elegans}

Analysis of oxidative stress is important for pharmacological and toxicological research because reactive oxygen species (ROS) may modulate or even destroy central cellular parameters. ROS originate from exogenous sources like UV irradiation or environmental toxins, but, also from endogenous sources. The main site of intracellular ROS production is the electron transport chain in the mitochondria. Other endogenous sources of ROS are intracellular enzymatic systems like the NADPH oxidase family, lipoxygenases, cytochrome P450, and the peroxisome (reviewed by [49]). Redox-active heavy metal ions like $\mathrm{Fe}^{2+}$ and $\mathrm{Cu}^{2+}$ also lead to the generation of ROS through fenton-like reactions [50]. Since ROS generation is the physiological result of every aerobic metabolism, it seems to be necessary for the viability of the cell. Low concentrations of ROS are needed for transducing cellular signals in various processes like proliferation, apoptosis, inflammation, and immune response [51]. On the other hand, an excess of these highly reactive molecules can cause severe damage to cellular molecules resulting in lipid peroxidation, oxidation of DNA bases, as well as protein modifications leading to modified activities. Since mitochondria are especially sensitive to oxidative stress due to high concentrations of radicals like superoxide anions $\left(\mathrm{O}_{2}{ }^{-}\right)$, an increase in ROS will disturb the mitochondrial electron transport chain resulting in an impaired energy production. Therefore ROS have to be inactivated by different endogenous antioxidant mechanisms, for example, antioxidant enzymes like superoxide dismutases (SOD), and glutathione peroxidases (GPO), and catalase (CAT), or low molecular antioxidants like glutathione (Figure 2). If the generation of ROS exceeds the antioxidant potency, accumulation of these oxidised toxic molecules in tissues leads to the phenomenon of so-called "oxidative stress" [52, 53]. On the cellular level, oxidative stress may cause the induction of apoptotic cell death or a disruption of intracellular signal transduction pathways [54].

The ageing process is associated with an increase in oxidative stress leading to impaired function and reproductivity of the cell as well as gene mutations which result in an increased likelihood for degenerative diseases and cancer [55]. In fact, oxidative stress is an important risk factor for many human diseases, for example, cardiovascular diseases [56], neurological disturbances such as morbus Alzheimer 
<smiles>O=c1c(O)c(-c2ccc(O)c(O)c2)oc2cc(O)cc(O)c12</smiles><smiles>O=c1c(O)c(-c2cc(O)c(O)c(O)c2)oc2cc(O)cc(O)c12</smiles><smiles>COc1cc(-c2oc3cc(O)cc(O)c3c(=O)c2O)ccc1O</smiles><smiles>COc1ccc(-c2oc3cc(O)cc(O)c3c(=O)c2O)cc1O</smiles><smiles>O=c1c(O)c(-c2ccc(O)cc2)oc2cc(O)cc(O)c12</smiles><smiles>O=c1cc(-c2ccccc2)oc2cc(O)c(O)c(O)c12</smiles><smiles>COc1ccc(-c2oc3c(CC=C(C)C)c(OC4OC(CO)[C@@H](O)[C@H](O)[C@H]4O)cc(O)c3c(=O)c2OC2OC(C)[C@@H](O)[C@H](O)[C@H]2O)cc1</smiles><smiles>Oc1cc(O)c2c(c1)O[C@H](c1ccc(O)c(O)c1)[C@H](O)C2</smiles><smiles>Oc1cc(O)c2c(c1)O[C@H](c1ccc(O)c(O)c1)[C@H](O)C2</smiles>

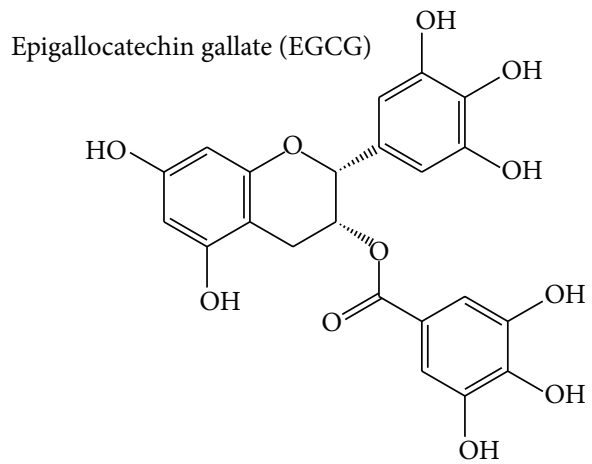

FIGURE 1: Major flavonoids studied in C. elegans. 


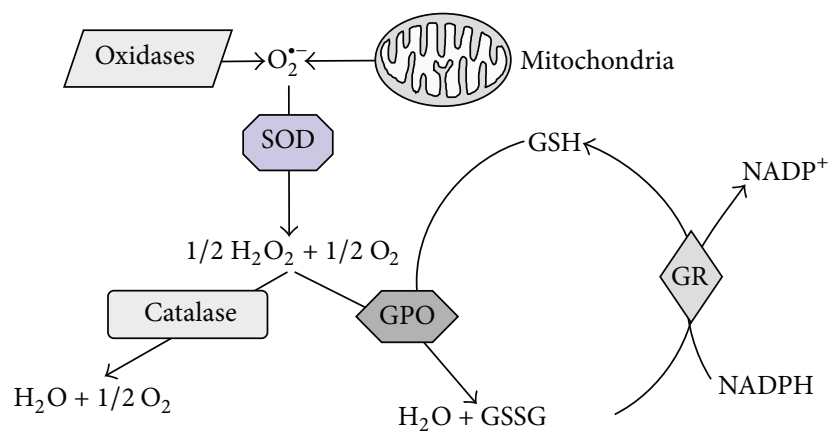

FIGURE 2: Schematic illustration of the endogenous defence system against intracellular oxidative stress. CAT: catalase, GPO: glutathione peroxidase, GR: glutathione reductase, GSH/GSSG: reduced glutathione/oxidized glutathione, SOD: superoxide dismutase.

(reviewed by [57]), cancer [58], and chronic obstructive pulmonary disease [59]. Therefore substances that have the ability to reduce oxidative stress have been in the focus of pharmacological research for a long time. The use of flavonoids which were found to act as radical scavengers as well as indirect antioxidants may be a promising intervention strategy to prevent these age-associated diseases.

\subsection{The Influence of Flavonoids on the Basal Oxidative Stress} Level in C. elegans (Physiological Conditions). Flavonoids have the potential to modulate intracellular oxidative stress directly by scavenging free radicals. In C. elegans intracellular ROS levels can be determined by the use of fluorescent probes, for example, $\mathrm{H}_{2}$ DCF-DA, MitoTracker Red, or CMH2XRos.

\subsubsection{Effects of Flavonoids on ROS Level and Oxidative Cell} Damage in C. elegans (Direct Antioxidative Effects). Several flavonoids were shown to reduce basal ROS levels in $C$. elegans [36, 44, 60-62].

Quercetin and the structural related flavonols myricetin, and kaempferol (each $100 \mu \mathrm{M}$ for $48 \mathrm{~h}$ ) decreased mitochondrial ROS levels in C. elegans by about $70 \%, 60 \%$, and $20 \%$, whereas naringenin did not show significant effects [36]. The authors explained that the differences between the the ROS reducing capacity were due to the structural nature of the substances (Figure 1). The 3-OH group and the double-bond in the C-ring, which are missing in naringenin, seem to be necessary for the mtROS scavenging effect and the catechol function in the B ring is thought to enhance the antioxidative effect in C. elegans. However, the methods for detecting ROS in C. elegans vary: While Grünz et al. [36] analysed mitochondrial ROS accumulation (MitoTracker Red, CMH2XRos) in the living nematode, other researchers determined the influence of flavonoids on total intracellular ROS levels $\left(\mathrm{H}_{2} \mathrm{DCF}-\mathrm{DA}\right)$ by analysing sonificated nematodes. For example, Gonzáles-Manzano et al. [61] showed that $200 \mu \mathrm{M}$ of epicatechin reduced basal levels of intracellular ROS by $10 \%$ in the nematode [61]. In addition it has been observed that EGCG decreased basal $\mathrm{H}_{2} \mathrm{O}_{2}$ levels in $C$. elegans in a dose-dependent manner whereby the most efficient dose ( $220 \mu \mathrm{M}$ EGCG for $72 \mathrm{~h}$ ) reduced $\mathrm{H}_{2} \mathrm{O}_{2}$ levels by about $32 \%$ $[44,60]$.

An increase of intracellular ROS concentrations may lead to oxidative stress associated cell damage. In order to investigate whether flavonoids are also protective against this kind of cell damage protein and lipid oxidations products were measured. To the best of our knowledge, the influence of flavonoids on DNA oxidation has not been investigated in C. elegans so far.

Icariside II, myricetin, quercetin and its methylated forms isorhamnetin and tamarixetin were found to protect against protein oxidation in C. elegans $[34,36]$. Grünz et al. [36] studied the effect of different flavonoid compounds on the level of proteincarbonyls which emerge during oxidation of protein amino acid side chains or indirect modifications due to products of lipid peroxidation or glycation [63]. The author showed that $100 \mu \mathrm{M}$ of quercetin or myricetin decreased proteincarbonyl levels by 60 and 50\%, respectively [36].

Cai et al. [40] investigated the influence of the bioactive flavonol-diglycoside icariside II from Herba epimedii on polyglutamine (polyQ) aggregation in the AM140 C. elegans strain which expresses polyQ fused to the yellow fluorescent protein (YFP) in body wall muscle cells. Mutated proteins with an elongated GAC sequence coding for glutamine cause the neurodegenerative Huntington's disease. The aggregation of these polyQ containing proteins is induced by oxidative stress and related to the pathogenesis of the disease [64]. Therefore transgene polyQ::YFP $C$. elegans are used as a model to analyse the oxidation status of proteins [65]. $20 \mu \mathrm{M}$ of icariside II was shown to significantly decrease formation of polyQ aggregates in the worms at days 4 and 6 of adulthood compared to untreated controls [40]. The polyQ induced paralysis phenotype of the worms was also decreased by icariside II.

Moreover, Mohri-Shiomi and Garsin [65] investigated the capacity of EGCG to protect against infection mediated cell damage in C. elegans. $25 \mu \mathrm{M}$ of EGCG was shown to reduce (1.9-fold) polyglutamine accumulation after pathogen (E. faecalis, day 2) infection in AM141 C. elegans expressing polyQ::YFP only in the intestine compared to the control. Therefore the authors suggested that EGCG protects against infection induced oxidative protein damage [65].

Another method to determine direct antioxidative effects of flavonoids in C. elegans is the analysis of lipid oxidation by measuring levels of lipofuscin. This autofluorescent pigment consists of oxidised cross-linked lipidperoxide products and partly oxidised proteins which cannot be degraded by the lysosome and thus accumulate within the cell in an agedependent manner $[66,67]$. In C. elegans lipofuscin particles can be seen throughout the gut and serve as ageing markers reflecting oxidative cell damage [68]. Flavonoids decrease the accumulation of lipofuscin pigments in C. elegans (Table 3) indicating that these plant compounds possess a protective effect towards age-associated oxidative cell damage [30, 35, 37, 38, 45, 69]. For example, Kampkötter et al. [30, 37] demonstrated that $100 \mu \mathrm{M}$ of quercetin (48 to $72 \mathrm{~h}$ ) reduced lipofuscin accumulation by $40 \%$ in seven-day-old C. elegans. Similar results were obtained by Pietsch et al. [35] where 
TABLE 3: Influence of flavonoids and flavonoid-rich extracts on lipofuscin levels in C. elegans.

\begin{tabular}{|c|c|c|c|c|}
\hline \multirow{2}{*}{$\begin{array}{l}\text { Compound } \\
\text { Flavonoid: } \\
\text { EGCG }\end{array}$} & \multicolumn{2}{|c|}{ Treatment/incubation time } & \multirow{2}{*}{$\begin{array}{c}\begin{array}{c}\text { Lipofuscin } \\
\text { reduction }(\%)\end{array} \\
39\end{array}$} & \multirow{2}{*}{$\frac{\text { References }}{\text { Abbas and Wink, } 2010 \text { [69] }}$} \\
\hline & $220 \mu \mathrm{M}$ & $\begin{array}{c}16 \text { days } \\
\text { (starting one day after hatching) }\end{array}$ & & \\
\hline Fisetin & $100 \mu \mathrm{M}$ & $\begin{array}{c}\text { 4th day of adulthood } \\
\text { (starting from L4) (7 days old) }\end{array}$ & No difference & Kampkötter et al., 2007 [70] \\
\hline Kaempferol & $100 \mu \mathrm{M}$ & $\begin{array}{c}\text { 4th day of adulthood } \\
\text { (starting from L4) (7 days old) }\end{array}$ & 25 & Kampkötter et al., 2007 [70] \\
\hline Myricetin & $100 \mu \mathrm{M}$ & $\begin{array}{c}\text { 4th day of adulthood } \\
\text { (starting from L4) (7 days old) }\end{array}$ & 33 & Büchter et al., 2013 [38] \\
\hline \multirow{2}{*}{ Quercetin } & $100 \mu \mathrm{M}$ & 7th day of adulthood (3 days) & 40 & Surco-Laos et al., 2012 [42] \\
\hline & $200 \mu \mathrm{M}$ & $\begin{array}{c}\text { 4th day of adulthood } \\
\text { (starting from L1) (7 days old) }\end{array}$ & 16 & Pietsch et al., 2011 [35] \\
\hline $\begin{array}{l}\text { Flavonoid rich extract: } \\
\text { blueberry polyphenols }\end{array}$ & $200 \mu \mathrm{g} / \mathrm{mL}$ & $\begin{array}{c}\text { Day } 16 \\
\text { (starting from the first day of adulthood) }\end{array}$ & 20 & Wilson et al., 2006 [45] \\
\hline
\end{tabular}

a treatment with $200 \mu \mathrm{M}$ quercetin resulted in a $16 \%$ decrease of lipofuscin autofluorescence at day 7 of adulthood. $C$. elegans treated with kaempferol or myricetin $(100 \mu \mathrm{M})$ did also show diminished lipofuscin autofluorescence whereas rutin and fisetin did not influence lipofuscin levels in the worm $[37,38,70]$. Further on, daily administration of $220 \mu \mathrm{M}$ of EGCG for 16 days decreased lipofuscin levels by about $39 \%$ in sterile fem-1 C. elegans compared to the control [69]. Analogous effects were observed for blueberry polyphenols [45]. Additionally the authors measured levels of 4Hydroxynonenal (4-HNE), a secondary oxidation product of lipids accumulating in an age-dependent manner in various species. Treatment with a flavonoid rich blueberry extract significantly reduced 4-HNE levels in the pharynx and the somatic gonads of 14-day-old C. elegans.

\subsubsection{Modulation of Antioxidant Enzymes by Flavonoids} in C. elegans (Indirect Antioxidant Effects). Flavonoids are able to modulate oxidative stress not just directly but also indirectly by modulating antioxidative enzymes (SOD-3, CAT, GPO, and glutathione-S-transferase (GST)). To analyse these effects, transgenic C. elegans were used, for example, nematodes expressing the green fluorescent protein (GFP) under the control of the promoter of these marker genes. In addition mRNA expression of antioxidative enzymes was determined.

For EGCG it has been shown that $0.1 \mu \mathrm{g} / \mathrm{mL}$ of the flavonoid upregulates SOD-3 expression by $49 \%$ [71]. Quercetin treatment of C. elegans resulted in a 15\% decreased expression of the antioxidant marker enzyme SOD-3 [30]. The authors proposed that the reduction of SOD-3 expression may be the result of the direct antioxidant effects of the flavonoid as it was observed that quercetin reduces ROS levels under diverse stress conditions [30,37].

Kampkötter et al. [48] did also study the effect of the Ginkgo biloba extract EGb 761 on antioxidant enzyme expression levels. It was shown that this extract suppressed GST-4 protein expression by $28 \%$. Additionally the plant extract treatment resulted in a $32 \%$ reduction of catalase transcription levels in the nematodes. These results may also reflect direct antioxidant effects of the plant extract. In conclusion, various flavonoids, depending on their structural properties, were experimentally shown to decrease oxidative stress in C. elegans under basal conditions.

3.2. Influence of Flavonoids on Oxidatively Stressed C. elegans (Pathophysiological Conditions). To simulate oxidative stress the nematodes are treated with redox cyclers (e.g., juglone) or hydrogen peroxide. Another possibility is the use of mutant strains producing large amounts of ROS. For example, mev$1(k n) C$. elegans are hypersensitive to oxidative stress due to a functional loss of a subunit of the enzyme succinate dehydrogenase cytochrome $b$ (complex II in the electron transport chain) [72]. To analyse the effects of flavonoids on ROS levels, antioxidant marker enzymes and survival rates of oxidatively stressed nematodes are analysed after flavonoid or vehicle treatment.

3.2.1. Effects of Flavonoids on ROS Level and Stress Resistance in Oxidatively Stressed C. elegans (Direct Antioxidant Effect). EGCG [71], aspalathin [62], myricetin, quercetin, and kaempferol [36] were found to be effective in lowering ROS levels in C. elegans. Zhang et al. [71] demonstrated that oxidatively stressed ( $1 \mathrm{~h}$ juglone) nematodes pretreated with $0.1 \mu \mathrm{g} / \mathrm{mL}$ EGCG (for $48 \mathrm{~h}$ ) showed significantly lower levels of ROS than untreated controls. In addition Chen et al. [62] showed that $50 \mu \mathrm{M}$ of aspalathin decreased ROS levels by about $42 \%$ in $m e v-1(k n)$. Similar results were obtained for myricetin, quercetin, and kaempferol as mitochondrial ROS levels were diminished by 45,60 , and $23 \%$ in $\operatorname{mev}-1(\mathrm{kn}) \mathrm{C}$. elegans [36].

Flavonoids were also reported to act as potent mediators of oxidative stress tolerance in $C$. elegans. For example, $100 \mu \mathrm{M}$ of quercetin enhanced survival times of C. elegans incubated with hydrogen peroxide [31] or the redox-cycler juglone [30] as chemical stressors by about $20 \%$. In addition, Surco-Laos et al. [34] showed that $200 \mu \mathrm{M}$ of quercetin 
enhanced mean survival rates by $12 \%$ under juglone treatment while the methylated derivatives isorhamnetin and tamarixetin showed slightly weaker effects (9 and 10\%). The authors also demonstrated that the flavonoids are more protective when oxidative stress occurs in a later stage of adulthood (6th day) than in the first day of adulthood.

Catechin, epicatechin, and its methylated derivatives increased survival rates up to about 1.4-fold [42]. In addition, EGCG enhanced survival rates of C. elegans about 3.9-fold [44]. Quercetin $(200 \mu \mathrm{M})$ [32] and EGCG $(50 \mu \mathrm{M})$ [44] also increased mean life span of mev-1 $(\mathrm{kn})$ mutants by $10 \%$ and $16 \%$ indicating that these flavonoids induce oxidative stress tolerance in C. elegans [44].

Some flavonoid rich plant extracts were shown to influence oxidative stress resistance in C. elegans while others did not mediate any effects. The catechol-rich Willow bark extract increased survival rates of C. elegans under tertbutylhydroperoxide induced oxidative stress up to $33 \%$ while the blueberry extract did not show significant effects [45]. Procyanidines from blueberris [45] or apples [47] did also not enhance mean life span of mev-1 $(\mathrm{kn}) \mathrm{C}$. elegans. Therefore, Sunagawa et al. [47] assumed that the analysed procyanidins possess no antioxidant effect in C. elegans which mediates life span expansion.

3.2.2. Modulation of Antioxidant Enzymes by Flavonoids in Oxidatively Stressed C. elegans (Indirect Antioxidant Effects). Kampkötter et al. [37, 48, 70] studied the effects of different flavonoids on the protein expression level of the marker enzyme GST-4 under juglone-induced oxidative stress. Quercetin treatment was shown to decrease GST-4 expression by $50 \%$ in transgenic worms under oxidative stress [37]. Kaempferol, rutin, and fisetin did also mediate a 45, 15 , and $10 \%$ decline of the GST-4::GFP level in C. elegans $[37,70]$. In addition C. elegans showed a reduction of GST4 expression by $35 \%$ when treated with the flavonoid-rich Ginkgo biloba extract EGb 761 [48].

3.3. Influence of Flavonoids on ROS Levels and the Stress Resistance in C. elegans under Thermal Stress. An increase of the temperature from $20^{\circ} \mathrm{C}$ (basal) to $35-37^{\circ} \mathrm{C}$ is lethal to $C$. elegans. This thermal stress is accompanied by an increase in ROS as well as an increase in nonfunctional proteins.

\subsubsection{Effects of Flavonoids on ROS Level and Stress Resistance} in C. elegans under Thermal Stress (Direct Antioxidant Effect). Various types of flavonoids were able to diminish oxidative stress levels induced by heat [37-39, 48, 61, 70]. For example, epicatechin treatment decreased intracellular levels of ROS by 24 to $28 \%$ [61]. In addition thermal stress induced increase of oxidative stress was reduced by $100 \mu \mathrm{M}$ of quercetin and, to a lesser extent, rutin [37]. Kaempferol, fisetin, baicalein, and myricetin did also decrease intracellular levels of ROS after 4 to $6 \mathrm{~h}$ of thermal stress $[38,39,70]$. Moreover $100 \mu \mathrm{g} / \mathrm{mL}$ of the Ginkgo biloba extract EGb 761 decreased intracellular ROS levels in C. elegans by about 30\% after thermal stress exposure [48].
Various types of flavonoids were also shown to enhance life span of C. elegans under thermal stress [31, 32, 34, 37, 41, $42,44,45,48,73]$. Treatment with quercetin increased mean survival times under thermal stress by about $12 \%$ to $30 \%$ $[32,34,37,41]$. The methylated derivatives isorharmnetin and tamarixetin showed even more powerful effects by enhancing mean survival times by 39\% [34]. EGCG, catechin, epicatechin, and $3^{\prime} / 4^{\prime}-\mathrm{O}$-methylepicatechin were shown to increase survival rates of C. elegans by approximately $9 \%$ to $28 \%[41,42,44]$. Further on Wilson et al. [45] showed that proanthocyanidins from blueberries enhanced the survival rates 2.5-fold. The flavonoid rich Ginkgo biloba extract EGb 761 and taxifolin did also increase thermotolerance in $C$. elegans $[48,73]$.

3.3.2. Modulation of Antioxidant Enzymes by Flavonoids in C. elegans under Thermal Stress (Indirect Antioxidant Effects). The modulation of antioxidative enzymes during thermal stress conditions is also affected by flavonoids. GonzálesManzano et al. [61] studied the influence of epicatechin on the expression levels of GPO in C. elegans under thermal stress. Under these conditions $200 \mu \mathrm{M}$ of epicatechin tend to diminish the expression of GPO in GPO::GFP C. elegans [61]. Kampkötter et al. [37, 48, 70] showed that Ginkgo biloba extract EGb 761 reduces GST-4 expression during thermal stress.

\section{Modulation of Representative Redox-Sensitive Signalling Pathways}

Oxidative stress results in the activation of a variety of intracellular signalling pathways in C. elegans resulting in an altered gene expression which determines cellular fate. Hence, several pathways induce cellular defence and adaption systems; others mediate proliferation or even apoptosis. The mitogen activated kinases ERK, JNK, and p38 as well as the Phosphatidylinositol-4,5-bisphosphate 3-kinase (PI3K)/Akt pathway belong to the major stress activated signalling pathways. While ERK and AKT exert cytoprotection, JNK and p38 are commonly associated with programmed cell death upon oxidative stress (review by [74]).

To analyse the molecular effects of flavonoids, the investigation of signalling pathways is crucial. In this review we show studies on modulation of selected cellular pathways involved in stress response and ageing by flavonoids. Table 4 gives an overview of the main regulatory ageing-associated genes in C. elegans and their mammalian homologues.

\subsection{Insulin/IGF-I Signalling Pathway}

4.1.1. The Insulin/Insulin Like Growth Factor (IGF)-I Signalling Pathway. The Insulin/Insulin like growth factor (IGF-)I signalling pathway is an evolutionary conserved mechanism that influences longevity and metabolism throughout different species (reviewed in [75]). In C. elegans this kinase cascade is required for the formation of the dauer larval stage and ageing [76]. The initiation of the cascade depends on the phosphorylation of DAF-2, the C. elegans homologue for 
TABLE 4: Regulatory ageing-associated genes in C. elegans and their mammalian homologues.

\begin{tabular}{ll}
\hline C. elegans gene & Mammalian homologue \\
\hline age-1 & Phosphatidylinositol 3-kinase \\
akt-1, akt-2 & Serine/threonine kinase Akt/PKB \\
daf-12 & Nuclear receptor FXR \\
daf-16 & FOXO transcription factor \\
daf-2 & Insulin receptor, IGF-IR, IRR \\
$h s f-1$ & Heat shock factor 1 \\
ins-1 bis 37 & Insulin like peptide, IGF-I, IGF-II \\
pdk-1 & 3-Phosphoinositide-dependent kinase 1 \\
$s k n-1$ & Nrf-2 transcription factor \\
\hline
\end{tabular}

Age: AGEing alteration; akt: AKT kinase family, daf: abnormal DAuer formation; FXR: farnesoid X receptor; FOXO: forkhead box O; IGF: insulinlike growth factor; Nrf: nuclear factor erythroid 2-related factor 2; skn: SKiNhead; ins: INSulin related.

the Insulin/IGF-1 receptor, which, in turn, leads to the activation of phosphoinosite-3-kinase (PI3K) encoded by age-1, 3phosphoinositide-dependent kinase-1 (PDK-1), AKT-1, AKT2 , and serum- and glucocorticoid-inducible kinase 1 (SGK-1). Activation of the insulin/IGF-I signalling pathway results in nuclear exclusion and thus inactivation of the forkhead transcription factor DAF-16. The heat-shock transcription factor HSF-1 and the Nrf-like xenobiotic-response factor SKN-1 are also affected by DAF-2 (reviewed in [77, 78]). Vice versa, the inhibition of the DAF-2 pathway leads to nuclear localisation and activation of the transcription factors, which changes the expression of various genes responsible for endogenous stress-response, development, metabolism, and longevity [77]. Mutations affecting components of the insulin/IGF-1 signalling pathway were found to expand the life span of nematodes by more than two times compared to wild-type worms $[79,80]$. In the last years it has been found that various classes of flavonoids seem to influence this pathway $[32,36,37,41,43,45,46,60,62,69-71]$. A schematic overview is shown in Figure 3.

4.1.2. Influence of Flavonoids on daf-2 Expression in $C$. elegans. Xue et al. [33] studied the influence of the newly isolated quercetin derivative from onions, quercetin 3-O$\beta$-D-glucopyranoside $(4 \rightarrow 1)$ - $\beta$-D-glucopyranoside (Q3M), on the gene expression of the insulin receptor daf-2 in $C$. elegans. In this context it was shown that Q3M increased (1.38-fold) daf-2 gene expression in the nematode compared to the control. In contrast, apigenin was found to inhibit daf-2 expression [81].

4.1.3. Influence of Flavonoids on daf-16 Gene Expression in C. elegans. Aspalathin (dihydrochalcone glycoside) from rooibos tea increased the daf-16-mRNA expression (1.2-fold) of $C$. elegans compared to untreated animals [62].

4.1.4. Flavonoids Increase DAF-16 Translocation from the Cytosol into the Nucleus in C. elegans. The intracellular localisation of the transcription factor DAF-16 was analysed

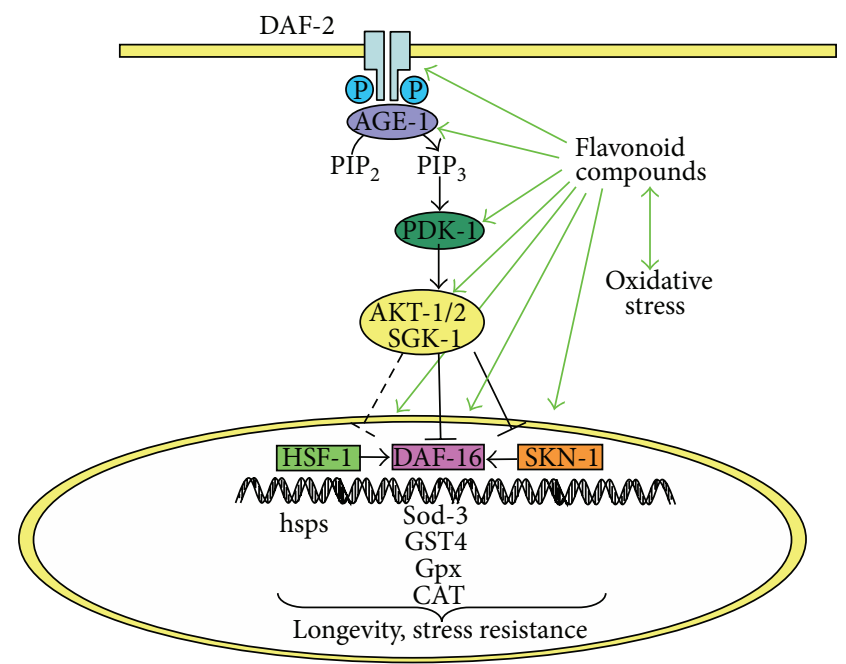

FIGURE 3: Simplified scheme of the DAF-16 signalling pathway in $C$. elegans representing molecular targets for modulation by flavonoids.

by means of transgenic C. elegans expressing a DAF-16::GFP fusion protein under the control of the DAF-16 promoter. Treatment with $220 \mu \mathrm{M}$ EGCG (for $1 \mathrm{~h}$ ) resulted in in a rapid nuclear translocation of DAF-16 [69]. Analogous results were obtained by Bartholome et al. [43], where a treatment of $100 \mu \mathrm{M}$ EGCG for $48 \mathrm{~h}$ increased (2.2-fold) the amount of worms showing predominantly nuclear localisation of DAF16 in contrast to untreated C. elegans. Similar effects were also found for quercetin [30, 36, 37], myricetin [36, 38], kaempferol, naringenin [36], fisetin [70], and apigenin [81], but not for rutin [37]. Remarkably, a $48 \mathrm{~h}$ pretreatment with $100 \mu \mathrm{M}$ quercetin enhanced the mean percentage of worms carrying predominantly nuclear DAF-16 by more than three times in contrast to untreated nematodes $[30,36,37,70]$.

4.1.5. Flavonoid Treatment Increases Expression of DAF-16 Targets in C. elegans. A modulation of the DAF-16 signalling pathway can be investigated by analysing the downstream targets of DAF-16: sod-3 [82], metallothionein [83], catalase genes ctl-1 and ctl-2, gst-4 [84], and small heat shock protein (hsp) genes.

In this context it has been demonstrated that EGCG and aspalathin significantly upregulate sod-3 mRNA expression by $70 \%$ and $320 \%$ in C. elegans compared to the control $[62,71]$. EGCG, myricetin, kaempferol, and fisetin did also enhance the expression of SOD-3 in transgenic SOD-3::GFP C. elegans $[36,71]$. An overview of flavonoids on DAF-16translocation, DAF-16-mediated gene expression, and DAF16 target protein levels is summarized in Table 5.

4.1.6. Influence of Flavonoids on the Insulin/IGF-1 Signalling Investigations with Mutant C. elegans Strains. Using mutant nematode strains lacking the function of key genes involved in the insulin/IGF-1 signalling pathway has been an elegant way to study the potential of flavonoids to mediate stress tolerance and extend life span. 
TABLE 5: Modulation of gene expression and protein localisation of DAF-16 and its target SOD-3.

\begin{tabular}{|c|c|c|}
\hline Effect & Flavonoid & Reference \\
\hline Increased daf-16 mRNA expression & Aspalathin & Chen et al., 2013 [62] \\
\hline \multirow{11}{*}{ Nuclear translocation of DAF-16 } & Apigenin & Kawasaki et al., 2010 [81] \\
\hline & \multirow{2}{*}{ EGCG } & Abbas and Wink, 2010 [69] \\
\hline & & Bartholome et al., 2010 [43] \\
\hline & Fisetin & Kampkötter et al., 2007 [70] \\
\hline & Kaempferol & Kampkötter et al., 2007 [70] \\
\hline & \multirow{2}{*}{ Myricetin } & Grünz et al., 2012 [36] \\
\hline & & Büchter et al., 2013 [38] \\
\hline & \multirow[t]{2}{*}{ Naringenin } & Grünz et al., 2012 [36] \\
\hline & & Kampkötter et al., 2007 [37] \\
\hline & \multirow[t]{2}{*}{ Quercetin } & Kampkötter et al., 2008 [30] \\
\hline & & Grünz et al., 2012 [36] \\
\hline \multirow{3}{*}{ Increased sod-3 mRNA } & Apigenin & Kawasaki et al., 2010 [81] \\
\hline & Aspalathin & Chen et al., 2013 [62] \\
\hline & EGCG & Zhang et al., 2009 [71] \\
\hline \multirow{4}{*}{ Increased SOD-3 protein level } & EGCG & Zhang et al., 2009 [71] \\
\hline & Fisetin & Grünz et al., 2012 [36] \\
\hline & Kaempferol & Grünz et al., 2012 [36] \\
\hline & Myricetin & Grünz et al., 2012 [36] \\
\hline
\end{tabular}

Brown et al. [60] showed that $25 \mu \mathrm{M}$ EGCG does not provoke a significant change in the intracellular ROS level of daf-16 (loss of function) mutant C. elegans, while in the wild-type strain ROS levels are significantly reduced by the flavonoid. This indicates that EGCG decreases ROS levels in the nematode in a DAF-16-dependent manner. Similar results were obtained with procyanidins from cocoa powder whereby DAF-16 was shown to be involved in the resistance of C. elegans against $\mathrm{H}_{2} \mathrm{O}_{2}$-induced stress [46]. Büchter et al. [38] showed that myricetin significantly decreases ROS production in wild-type nematodes for up to $6 \mathrm{~h}$ while in $d a f-$ 16 (mu86) mutants a decrease was only detectable in early time points (2-3 h). Grünz et al. analysed the same compound under basal conditions and showed comparable protective effects in regard to oxidative stress levels in wild-type and daf-16 mutant worms. This indicates that low levels of ROS as observed under short thermal stress and physiological conditions may be inactivated by direct antioxidant effects (radical scavenging) of myricetin while high concentrations of ROS can only be reduced via an indirect antioxidant mechanism. In addition, Grünz et al. [36] did also show that the quercetin and kaempferol-mediated decrease of mitochondrial ROS level did not depend on daf-16 activity under basal conditions.

There have been conflicting results in regard to the involvement of the DAF-2 pathway in flavonoid-mediated longevity of $C$. elegans. On the one side, Pietsch et al. [32] showed that $200 \mu \mathrm{M}$ of quercetin did not extend the life span of the mutant strains daf-2(e1368) and age-1(hx546) compared to untreated controls indicating that these key genes of the insulin/IGF-1 pathway are involved in longevity regulation of $C$. elegans. A supplementary meta-analysis of global transcriptomics showed that quercetin-treated worms share transcriptional patterns with $d a f-2$ and $d a f-12$ mutants [85] whereby DAF-12 is a nuclear hormone receptor in C. elegans affecting reproduction and arrest at the dauer diapause through insulin/IGF signalling [77]. Moreover, the flavonol diglycosides icariin and its conjugated form icariside II were found to mediate life span extension in a daf-2- and daf-16-dependent manner [40]. In addition catechin-induced expansion of life span seems to be in parts regulated by AKT$2[41]$.

On the other hand, the life span of quercetin treated daf-16 mutants ( $m g D f 50)$ was significantly increased in comparison to untreated mutant worms [32]. These results were confirmed by two other research groups, suggesting that life span extension induced by quercetin does not depend on DAF-16 activity and that the nuclear localisation of DAF-16 may not be a guaranty for longevity $[36,41]$. Comparable results were obtained for myricetin by Grünz et al. [36] while we showed that the flavonoid prolonged the life span in $C$. elegans via DAF-16 [38]. These different findings may be again the result of a different experimental handling and myricetin application: agar plates versus liquid culture and different temperatures.

Catechin- and proanthocyanidins- (from blueberries) mediated longevity in $C$. elegans were also found to be independent of $d a f-16$ gene expression when studying mutant strains $[41,45]$. In addition catechin induced longevity seems to be independent of the age-1 gene [41].

In conclusion it has been shown that structurally diverse flavonoids influence different regulatory components of the Insulin/IGF-1 like signalling pathway. Findings in regard to DAF-16 are inconsistent: DAF-16 translocation to the nucleus 
was shown for several compounds while gene expression seems to be just in parts affected. Therefore it is possible that the posttranscriptional regulation of DAF-16 is an important factor for the effects of flavonoids in C. elegans. Asides from that cofactors might be needed for gene expression of antioxidant enzymes and proteins. Therefore the interplay of different stress signalling pathways, with DAF-16 signalling being one of them, may result in increased stress resistance and longevity in C. elegans. Due to the important role of this pathway for pharmacology and toxicology, modulating effects of dietary flavonoids are getting more and more in the focus of scientific research.

4.2. Heat Shock Protein Response. Heat shock proteins are polypeptides protecting the cells from stress by mediating protein assembling, refolding, and translocation [86]. In $C$. elegans members of the HSP-16 protein family have been shown to be involved in thermotolerance and thus are suggested as predictors for longevity [87-89]. Further on, the expression of $h s p$ genes is mainly regulated by the heat shock transcription factor-1 (HSF-1) which is also influenced by the Insulin/IGF-1 signalling pathway in C. elegans $[88,90]$. Because of the pivotal role of HSP-16 proteins in the cellular stress response of $C$. elegans several researchers have focused on the influence of flavonoids on the expression of HSPs in this model organism. In this context HSP expression was measured by means of gene expression analysis or transgenic C. elegans expressing GFP under the control of various $h s p$ promoters $[44,45,62,69,73,91]$.

4.2.1. Influence of Flavonoids on hsp Gene Expression in C. elegans. (1) Influence of Flavonoids on hsp Gene Expression in C. elegans: Oxidative Stress. Oxidative stress generated by juglone has also been shown to increase HSP-16.2::GFP expression in transgenic nematodes compared to nonstressed animals. The flavonoid EGCG $(220 \mu \mathrm{M}$ EGCG for $48 \mathrm{~h})$ suppressed juglone-induced HSP-16.2 expression by about $73 \%$ in transgenic worms [44]. A prominent flavonoid from rooibos tea, aspalathin, showed comparable effects on the HSP level under oxidative stress [62]. In this case $20 \mu \mathrm{M}$ aspalathin (for $48 \mathrm{~h}$ ) decreased HSP-16.2 expression by $27 \%$ after acute oxidative stress in C. elegans [62].

The Gingko biloba extract EGb 761 showed a strong capacity in decreasing HSP-16.2 expression. A posttreatment with $100 \mu \mathrm{g} / \mathrm{mL}$ of EGb 761 significantly reduced oxidative stress-induced HSP-16.2 expression [91]. Nonetheless EGCG, aspalathin, and EGb 761 may differ in the way they interfere with HSP-16 since EGb 761 was only efficient in reducing HSP levels in transgenic C. elegans when posttreated to oxidative stress while EGCG and asphalatin showed significant effects when pretreated to oxidative stress $[44,91]$.

EGCG pretreatment reduced juglone-induced $h s p-16.1$ and $h s p-16.2$ mRNA expression by about $90 \%$ in the nematodes indicating that the flavonoid is a sufficient suppressor of $h s p-16.1$ and $h s p-16.2$ expression on the mRNA level [69].

(2) Influence of Flavonoids on hsp Gene Expression in C. elegans: Ageing. The hsp gene expression is not only induced by cellular stress but also rises with age [92]. Therefore Wilson et al. [45] studied the effect of blueberry polyphenols on $h s p$ mRNA expression in C. elegans between day 0 and day 4 of adulthood. The blueberry polyphenols treatment diminished the age-related increase of $h s p-12.6,-16.1,-16.49$, and -70 mRNA expression [45].

(3) Influence of Flavonoids on HSP::GFP Expression in Transgenic C. elegans: Thermal Stress. Strayer et al. [91] investigated the influence of the flavonoid-rich Ginkgo biloba EGb 761 extract on HSP-16.2 expression in heat stressed C. elegans. Thermal stress caused by a temperature rise to $35^{\circ} \mathrm{C}$ for $2 \mathrm{~h}$ was shown to increase HSP-16.2 levels in transgenic nematodes compared to nonstressed animals. Subsequently, a posttreatment with $100 \mu \mathrm{g} / \mathrm{mL}$ EGb 761 significantly suppressed stress-induced HSP-16.2 expression [91]. In contrast, Zhang et al. [71] studied the effect of EGCG on HSP-16.2 levels after transgenic C. elegans experienced a heat shock at $35^{\circ} \mathrm{C}$. Pretreatment with $0.1 \mu \mathrm{g} / \mathrm{mL}$ EGCG for $48 \mathrm{~h}$ resulted in a significant increase of HSP-16.2 expression by $11.9 \%$ in the transgenic nematodes after a $24 \mathrm{~h}$ recovering period of time.

4.3. Nrf2/SKN-1 Signalling Pathway. The nuclear factorerythroid-2-related factor 2 (Nrf2, SKN-1 C. elegans homologue) belongs to the basic leucine zipper (bZip) family and regulates the gene expression of phase II detoxifying enzymes and antioxidant proteins such as SOD, GST, GPO, or NAD $(\mathrm{P}) \mathrm{H}$ :quinone oxidoreductase (NQO-1). Under physiological conditions in mammals, Nrf2 is bound to Keap1 which retains Nrf2 in the cytoplasm. Oxidative stress induces dissociation of the Nrf2-Keap1 complex by modification of cysteine residues of Keap1. Nrf2 translocates into the nucleus where it dimerises with other bZip transcription factors like small-Maf proteins. The heterodimer binds to antioxidant response elements (ARE) in the promoter region of genes encoding phase II enzymes and antioxidant proteins leading to a changed expression profile $[93,94]$.

4.3.1. Flavonoids Increase SKN-1 Activation in C. elegans. Havermann et al. [39] demonstrated that flavonoids possess the ability to induce SKN-1 translocation into the nucleus and thus activate this transcription factor. Baicalein $(100 \mu \mathrm{M})$ increased the activation of the SKN-1 signalling pathway 4 -fold [39]. In contrast the flavonoid myricetin $(100 \mu \mathrm{M})$ did not induce SKN-1 activation [38]. These two examples show that structural differences like the positions of hydroxyl groups may be critical for modulation of SKN-1 activation. Ishikado et al. [95] studied the effect of willow bark extract (WBE) containing flavonoids on the expression of the SKN-1regulated antioxidant enzyme gamma-glutamylcysteine synthetase (gcs-1; glutamate cysteine ligase catalytic subunit (GCLC) homologue), the key enzyme for glutathione synthesis. For this purpose the researchers utilised transgenic C. elegans expressing GFP under the control of the $g c s-1$ promoter in the pharynx and ASI chemosensory neurons under basal conditions and in the intestine under oxidative stress. Treatment with $10 \mathrm{mg} / \mathrm{mL}$ of the Willow bark extract (WBE) for 90 min increased GCS-1::GFP expression by about 
$19 \%$ in comparison to the control. Moreover WBE treated GSC-1:: $\triangle 2:: G F P$ C. elegans lacking SKN-1-independent pharyngeal GCS-1 expression showed similar expression patterns as the GCS-1::GFP nematodes [95]. In addition transgene GCS-1:: $\triangle 2$ mut3::GFP animals lacking critical SKN-1 binding sites were also treated with WBE which did not result in an increased GFP expression. These experiments indicate that WBE increases gene expression of antioxidant enzymes in a SKN-1 dependent manner. The gene expression of skn-1 seems not to be involved in catechin-and PAC (from blueberries)-mediated longevity in C. elegans [41, 45]. Quantitative real-time PCR analysis was conducted to measure the effect of EGCG on $s k n$-1-mRNA expression in $C$. elegans and $s k n 1 \mathrm{mRNA}$ expression was shown to be increased in the nematode by $50 \%$ [71].

\section{Conclusion}

In the last years the model organism C. elegans has gained increasing importance in pharmacological and toxicological sciences due to the availability of various genetically modified nematode strains, the simplicity of modulating genes by RNAi, and the short life span. Several studies were performed demonstrating that secondary plant compounds influence ageing, stress resistance, and distinct signalling pathways in the nematode.

\section{Conflict of Interests}

The authors declare that there is no conflict of interests regarding the publication of this paper.

\section{References}

[1] G. Di Carlo, N. Mascolo, A. A. Izzo, and F. Capasso, "Flavonoids: old and new aspects of a class of natural therapeutic drugs," Life Sciences, vol. 65, no. 4, pp. 337-353, 1999.

[2] G. R. Beecher, "Proceedings of the third international scientific symposium on tea and human health: role of flavonoids in the diet. Overview of dietary flavonoids: nomenclature, occurrence and intake," The Journal of Nutrition, vol. 133, no. 10, pp. 3248S3254S, 2003.

[3] L. Mira, M. T. Fernandez, M. Santos, R. Rocha, M. H. Florêncio, and K. R. Jennings, "Interactions of flavonoids with iron and copper ions: a mechanism for their antioxidant activity," Free Radical Research, vol. 36, no. 11, pp. 1199-1208, 2002.

[4] E. Middleton Jr., C. Kandaswami, and T. C. Theoharides, “The effects of plant flavonoids on mammalian cells: implications for inflammation, heart disease, and cancer," Pharmacological Reviews, vol. 52, no. 4, pp. 673-751, 2000.

[5] C.-C. Chen, M.-P. Chow, W.-C. Huang, Y.-C. Lin, and Y.-J. Chang, "Flavonoids inhibit tumor necrosis factor- $\alpha$-induced up-regulation of intercellular adhesion molecule-1 (ICAM-1) in respiratory epithelial cells through activator protein-1 and nuclear factor- $\kappa \mathrm{B}$ : structure-activity relationships," Molecular Pharmacology, vol. 66, no. 3, pp. 683-693, 2004.

[6] T. L. Wadsworth, T. L. McDonald, and D. R. Koop, "Effects of Ginkgo biloba extract (EGb 761) and quercetin on lipopolysaccharide-induced signaling pathways involved in the release of tumor necrosis factor- $\alpha$, Biochemical Pharmacology, vol. 62, no. 7, pp. 963-974, 2001.

[7] D. S. Wheeler, J. D. Catravas, K. Odoms, A. Denenberg, V. Malhotra, and H. R. Wong, "Epigallocatechin-3-gallate, a green tea-derived polyphenol, inhibits IL- $1 \beta$-dependent proinflammatory signal transduction in cultured respiratory epithelial cells," The Journal of Nutrition, vol. 134, no. 5, pp. 1039-1044, 2004.

[8] M. P. Nair, S. Mahajan, J. L. Reynolds et al., "The flavonoid quercetin inhibits proinflammatory cytokine (tumor necrosis factor alpha) gene expression in normal peripheral blood mononuclear cells via modulation of the NF- $\kappa \beta$ system," Clinical and Vaccine Immunology, vol. 13, no. 3, pp. 319-328, 2006.

[9] M. L. Ferrándiz and M. J. Alcaraz, "Anti-inflammatory activity and inhibition of arachidonic acid metabolism by flavonoids," Agents and Actions, vol. 32, no. 3-4, pp. 283-288, 1991.

[10] M. Hämäläinen, R. Nieminen, P. Vuorela, M. Heinonen, and E. Moilanen, "Anti-inflammatory effects of flavonoids: genistein, kaempferol, quercetin, and daidzein inhibit STAT-1 and NF$\kappa \mathrm{B}$ activations, whereas flavone, isorhamnetin, naringenin, and pelargonidin inhibit only NF- $\kappa$ B activation along with their inhibitory effect on iNOS expression and NO production in activated macrophages," Mediators of Inflammation, vol. 2007, Article ID 45673, 10 pages, 2007.

[11] M. Lorenz, S. Wessler, E. Follmann et al., "A constituent of green tea, epigallocatechin-3-gallate, activates endothelial nitric oxide synthase by a phosphatidylinositol-3-OH-kinase-, cAMP-dependent protein kinase-, and Akt-dependent pathway and leads to endothelial-dependent vasorelaxation," The Journal of Biological Chemistry, vol. 279, no. 7, pp. 6190-6195, 2004.

[12] Y. Nagasaka and K. Nakamura, "Modulation of the heatinduced activation of mitogen-activated protein (MAP) kinase by quercetin," Biochemical Pharmacology, vol. 56, no. 9, pp. 11511155, 1998.

[13] A. K. Srivastava, "Inhibition of phosphorylase kinase, and tyrosine protein kinase activities by quercetin," Biochemical and Biophysical Research Communications, vol. 131, no. 1, pp. 1-5, 1985.

[14] M. Picq, A. F. Prigent, G. Némoz, A. C. André, and H. Pacheco, "Pentasubstituted quercetin analogues as selective inhibitors of particulate $3^{\prime}: 5^{\prime}$-cyclic-AMP phosphodiesterase from rat brain," Journal of Medicinal Chemistry, vol. 25, no. 10, pp. 1192-1198, 1982.

[15] F. Boege, T. Straub, A. Kehr et al., "Selected novel flavones inhibit the DNA binding or the DNA religation step of eukaryotic topoisomerase I," The Journal of Biological Chemistry, vol. 271, no. 4, pp. 2262-2270, 1996.

[16] A. R. Chowdhury, S. Sharma, S. Mandal, A. Goswami, S. Mukhopadhyay, and H. K. Majumder, "Luteolin, an emerging anti-cancer flavonoid, poisons eukaryotic DNA topoisomerase I," Biochemical Journal, vol. 366, no. 2, pp. 653-661, 2002.

[17] J. J. Van Zanden, O. B. Hamman, M. L. P. S. Van Iersel et al., "Inhibition of human glutathione S-transferase P1-1 by the flavonoid quercetin," Chemico-Biological Interactions, vol. 145, no. 2, pp. 139-148, 2003.

[18] Y.-Q. Wei, X. Zhao, Y. Kariya, H. Fukata, K. Teshigawara, and A. Uchida, "Induction of apoptosis by quercetin: involvement of heat shock protein," Cancer Research, vol. 54, no. 18, pp. 49524957, 1994.

[19] M. Richter, R. Ebermann, and B. Marian, "Quercetin-induced apoptosis in colorectal tumor cells: possible role of EGF receptor signaling," Nutrition and Cancer, vol. 34, no. 1, pp. 88-99, 1999. 
[20] N. Ahmad, P. Cheng, and H. Mukhtar, "Cell cycle dysregulation by green tea polyphenol epigallocatechin-3-gallate," Biochemical and Biophysical Research Communications, vol. 275, no. 2, pp. 328-334, 2000.

[21] R. L. Thangapazham, A. K. Singh, A. Sharma, J. Warren, J. P. Gaddipati, and R. K. Maheshwari, "Green tea polyphenols and its constituent epigallocatechin gallate inhibits proliferation of human breast cancer cells in vitro and in vivo," Cancer Letters, vol. 245, no. 1-2, pp. 232-241, 2007.

[22] H. P. Ciolino, P. J. Daschner, and G. C. Yeh, "Dietary flavonols quercetin and kaempferol are ligands of the aryl hydrocarbon receptor that affect CYP1A1 transcription differentially," Biochemical Journal, vol. 340, no. 3, pp. 715-722, 1999.

[23] S. Zhang, C. Qin, and S. H. Safe, "Flavonoids as aryl hydrocarbon receptor agonists/antagonists: effects of structure and cell context," Environmental Health Perspectives, vol. 111, no. 16, pp. 1877-1882, 2003.

[24] A. Ansarullah, B. Bharucha, M. Dwivedi et al., "Antioxidant rich flavonoids from Oreocnide integrifolia enhance glucose uptake and insulin secretion and protects pancreatic $\beta$-cells from streptozotocin insult," BMC Complementary and Alternative Medicine, vol. 11, no. 1, p. 126, 2011.

[25] E. M. Choi and Y. S. Lee, "Effects of hesperetin on the production of inflammatory mediators in IL- $1 \beta$ treated human synovial cells," Cellular Immunology, vol. 264, no. 1, pp. 1-3, 2010.

[26] J. Wei, S. Bhatt, L. M. Chang, H. A. Sampson, and M. Masilamani, "Isoflavones, genistein and daidzein, regulate mucosal immune response by suppressing dendritic cell function," PloS One, vol. 7, no. 10, Article ID e47979, pp. 1-11, 2012.

[27] J. J. Peterson, J. T. Dwyer, P. F. Jacques, and M. L. McCullough, "Associations between flavonoids and cardiovascular disease incidence or mortality in European and US populations," Nutrition Reviews, vol. 70, no. 9, pp. 491-508, 2012.

[28] D. F. Romagnolo and O. I. Selmin, "Flavonoids and cancer prevention: a review of the evidence," Journal of Nutrition in Gerontology and Geriatrics, vol. 31, no. 3, pp. 206-238, 2012.

[29] E. Nurk, H. Refsum, C. A. Drevon et al., "Intake of flavonoidrich wine, tea, and chocolate by elderly men and women is associated with better cognitive test performance ${ }^{1-3}$," The Journal of Nutrition, vol. 139, no. 1, pp. 120-127, 2009.

[30] A. Kampkötter, C. Timpel, R. F. Zurawski et al., "Increase of stress resistance and lifespan of Caenorhabditis elegans by quercetin," Comparative Biochemistry and Physiology Part B, vol. 149, no. 2, pp. 314-323, 2008.

[31] N. Saul, K. Pietsch, R. Menzel, and C. E. W. Steinberg, "Quercetin-mediated longevity in Caenorhabditis elegans: is DAF-16 involved?" Mechanisms of Ageing and Development, vol. 129, no. 10, pp. 611-613, 2008.

[32] K. Pietsch, N. Saul, R. Menzel, S. R. Stürzenbaum, and C. E. W. Steinberg, "Quercetin mediated lifespan extension in Caenorhabditis elegans is modulated by age- 1 , daf-2, sek-1 and unc43," Biogerontology, vol. 10, no. 5, pp. 565-578, 2009.

[33] Y.-L. Xue, T. Ahiko, T. Miyakawa et al., "Isolation and Caenorhabditis elegans lifespan assay of flavonoids from onion," Journal of Agricultural and Food Chemistry, vol. 59, no. 11, pp. 5927-5934, 2011.

[34] F. Surco-Laos, J. Cabello, E. Gómez-Orte et al., "Effects of O-methylated metabolites of quercetin on oxidative stress, thermotolerance, lifespan and bioavailability on Caenorhabditis elegans," Food and Function, vol. 2, no. 8, pp. 445-456, 2011.

[35] K. Pietsch, N. Saul, S. Chakrabarti, S. R. Stürzenbaum, R. Menzel, and C. E. W. Steinberg, "Hormetins, antioxidants and prooxidants: defining quercetin-, caffeic acid- and rosmarinic acid-mediated life extension in C. elegans," Biogerontology, vol. 12, no. 4, pp. 329-347, 2011.

[36] G. Grünz, K. Haas, S. Soukup et al., "Structural features and bioavailability of four flavonoids and their implications for lifespan-extending and antioxidant actions in C. elegans," Mechanisms of Ageing and Development, vol. 133, no. 1, pp. 1-10, 2012.

[37] A. Kampkötter, C. G. Nkwonkam, R. F. Zurawski et al., "Investigations of protective effects of the flavonoids quercetin and rutin on stress resistance in the model organism Caenorhabditis elegans," Toxicology, vol. 234, no. 1-2, pp. 113-123, 2007.

[38] C. Büchter, D. Ackermann, S. Havermann et al., "Myricetinmediated lifespan extension in Caenorhabditis elegans is modulated by DAF-16," International Journal of Molecular Sciences, vol. 14, no. 6, pp. 11895-11914, 2013.

[39] S. Havermann, R. Rohrig, Y. Chovolou, H.-U. Humpf, and W. Wätjen, "Molecular effects of baicalein in Hct116 cells and Caenorhabditis elegans: activation of the Nrf2 signalling pathway and prolongation of lifespan," Journal of Agricultural and Food Chemistry, vol. 61, no. 9, pp. 2158-2164, 2013.

[40] W.-J. Cai, J.-H. Huang, S.-Q. Zhang et al., "Icariin and its derivative icariside II extend healthspan via insulin/IGF-1 pathway in C. elegans," PLoS One, vol. 6, no. 12, Article ID e28835, 2011.

[41] N. Saul, K. Pietsch, R. Menzel, S. R. Stürzenbaum, and C. E. W. Steinberg, "Catechin induced longevity in C. elegans: from key regulator genes to disposable soma," Mechanisms of Ageing and Development, vol. 130, no. 8, pp. 477-486, 2009.

[42] F. Surco-Laos, M. Dueñas, S. González-Manzano, J. Cabello, C. Santos-Buelga, and A. M. González-Paramás, "Influence of catechins and their methylated metabolites on lifespan and resistance to oxidative and thermal stress of Caenorhabditis elegans and epicatechin uptake," Food Research International, vol. 46, no. 2, pp. 514-521, 2012.

[43] A. Bartholome, A. Kampkötter, S. Tanner, H. Sies, and L.-O. Klotz, "Epigallocatechin gallate-induced modulation of FoxO signaling in mammalian cells and C. elegans: FoxO stimulation is masked via PI3K/Akt activation by hydrogen peroxide formed in cell culture," Archives of Biochemistry and Biophysics, vol. 501, no. 1, pp. 58-64, 2010.

[44] S. Abbas and M. Wink, "Epigallocatechin gallate from green tea (Camellia sinensis) increases lifespan and stress resistance in Caenorhabditis elegans," Planta Medica, vol. 75, no. 3, pp. 216221, 2009.

[45] M. A. Wilson, B. Shukitt-Hale, W. Kalt, D. K. Ingram, J. A. Joseph, and C. A. Wolkow, "Blueberry polyphenols increase lifespan and thermotolerance in Caenorhabditis elegans," Aging Cell, vol. 5, no. 1, pp. 59-68, 2006.

[46] P. Martorell, J. V. Forment, R. De Llanos et al., "Use of Saccharomyces cerevisiae and Caenorhabditis elegans as model organisms to study the effect of cocoa polyphenols in the resistance to oxidative stress," Journal of Agricultural and Food Chemistry, vol. 59, no. 5, pp. 2077-2085, 2011.

[47] T. Sunagawa, T. Shimizu, T. Kanda, M. Tagashira, M. Sami, and T. Shirasawa, "Procyanidins from apples (Malus pumila Mill.) Extend the lifespan of Caenorhabditis elegans," Planta Medica, vol. 77, no. 2, pp. 122-127, 2011.

[48] A. Kampkötter, T. Pielarski, R. Rohrig et al., "The Ginkgo biloba extract EGb761 reduces stress sensitivity, ROS accumulation and expression of catalase and glutathione S-transferase 4 in Caenorhabditis elegans," Pharmacological Research, vol. 55, no. 2, pp. 139-147, 2007. 
[49] T. Finkel and N. J. Holbrook, "Oxidants, oxidative stress and the biology of ageing," Nature, vol. 408, no. 6809, pp. 239-247, 2000.

[50] S. J. Stohs and D. Bagchi, "Oxidative mechanisms in the toxicity of metal ions," Free Radical Biology and Medicine, vol. 18, no. 2, pp. 321-336, 1995.

[51] H. E. Seifried, D. E. Anderson, E. I. Fisher, and J. A. Milner, "A review of the interaction among dietary antioxidants and reactive oxygen species," The Journal of Nutritional Biochemistry, vol. 18, no. 9, pp. 567-579, 2007.

[52] H. Sies, "Strategies of antioxidant defense," European Journal of Biochemistry, vol. 215, no. 2, pp. 213-219, 1993.

[53] H. Sies, "Physiological symposium: impaired endothelial and smooth muscle cell function in oxidative stress; oxidative stress: oxidants and antioxidants," Experimental Physiology, vol. 82, pp. 291-295, 1997.

[54] H. M. Lander, "An essential role for free radicals and derived species in signal transduction," The FASEB Journal, vol. 11, no. 2, pp. 118-124, 1997.

[55] D. Harman, "Aging: a theory based on free radical and radiation chemistry," The Journal of Gerontology, vol. 11, no. 3, pp. 298300, 1956.

[56] U. Förstermann, "Oxidative stress in vascular disease: causes, defense mechanisms and potential therapies," Nature Clinical Practice Cardiovascular Medicine, vol. 5, no. 6, pp. 338-349, 2008.

[57] M. T. Lin and M. F. Beal, "Mitochondrial dysfunction and oxidative stress in neurodegenerative diseases," Nature, vol. 443, no. 7113, pp. 787-795, 2006.

[58] S. Reuter, S. C. Gupta, M. M. Chaturvedi, and B. B. Aggarwal, "Oxidative stress, inflammation, and cancer: how are they linked?" Free Radical Biology and Medicine, vol. 49, no. 11, pp. 1603-1616, 2010.

[59] H. S. Park, S. R. Kim, and Y. C. Lee, "Impact of oxidative stress on lung diseases," Respirology, vol. 14, no. 1, pp. 27-38, 2009.

[60] M. K. Brown, J. L. Evans, and Y. Luo, "Beneficial effects of natural antioxidants EGCG and $\alpha$-lipoic acid on life span and agedependent behavioral declines in Caenorhabditis elegans," Pharmacology Biochemistry and Behavior, vol. 85, no. 3, pp. 620-628, 2006.

[61] S. González-Manzano, A. M. González-Paramás, L. Delgado et al., "Oxidative status of stressed Caenorhabditis elegans treated with epicatechin," Journal of Agricultural and Food Chemistry, vol. 60, no. 36, pp. 8911-8916, 2012.

[62] W. Chen, I. R. Sudji, E. Wang, E. Joubert, B. E. Van Wyk, and M. Wink, "Ameliorative effect of aspalathin from rooibos (Aspalathus linearis) on acute oxidative stress in Caenorhabditis elegans," Phytomedicine, vol. 20, no. 3, pp. 380-386, 2013.

[63] I. Dalle-Donne, R. Rossi, D. Giustarini, A. Milzani, and R. Colombo, "Protein carbonyl groups as biomarkers of oxidative stress," Clinica Chimica Acta, vol. 329, no. 1-2, pp. 23-38, 2003.

[64] C. A. Ross and M. A. Poirier, "Protein aggregation and neurodegenerative disease," Nature Medicine, vol. 10, pp. S10-S17, 2004.

[65] A. Mohri-Shiomi and D. A. Garsin, "Insulin signaling and the heat shock response modulate protein homeostasis in the Caenorhabditis elegans intestine during infection," The Journal of Biological Chemistry, vol. 283, no. 1, pp. 194-201, 2008.

[66] D. Yin, "Biochemical basis of lipofuscin, ceroid, and age pigment-like fluorophores," Free Radical Biology and Medicine, vol. 21, no. 6, pp. 871-888, 1996.

[67] M. P. Gardner, D. Gems, and M. E. Viney, "Aging in a very shortlived nematode," Experimental Gerontology, vol. 39, no. 9, pp. 1267-1276, 2004.
[68] B. Gerstbrein, G. Stamatas, N. Kollias, and M. Driscoll, "In vivo spectrofluorimetry reveals endogenous biomarkers that report healthspan and dietary restriction in Caenorhabditis elegans," Aging Cell, vol. 4, no. 3, pp. 127-137, 2005.

[69] S. Abbas and M. Wink, "Epigallocatechin gallate inhibits beta amyloid oligomerization in Caenorhabditis elegans and affects the daf-2/insulin-like signaling pathway," Phytomedicine, vol. 17, no. 11, pp. 902-909, 2010.

[70] A. Kampkötter, C. G. Nkwonkam, R. F. Zurawski et al., "Effects of the flavonoids kaempferol and fisetin on thermotolerance, oxidative stress and FoxO transcription factor DAF-16 in the model organism Caenorhabditis elegans," Archives of Toxicology, vol. 81, no. 12, pp. 849-858, 2007.

[71] L. Zhang, G. Jie, J. Zhang, and B. Zhao, "Significant longevityextending effects of EGCG on Caenorhabditis elegans under stress," Free Radical Biology and Medicine, vol. 46, no. 3, pp. 414421, 2009.

[72] N. Ishii, M. Fujii, P. S. Hartman et al., "A mutation in succinate dehydrogenase cytochrome $b$ causes oxidative stress and ageing in nematodes," Nature, vol. 394, no. 6694, pp. 694-697, 1998.

[73] M. G. Benedetti, A. L. Foster, M. C. Vantipalli et al., "Compounds that confer thermal stress resistance and extended lifespan," Experimental Gerontology, vol. 43, no. 10, pp. 882-891, 2008.

[74] N. J. Holbrook and S. Ikeyama, "Age-related decline in cellular response to oxidative stress: links to growth factor signaling pathways with common defects," Biochemical Pharmacology, vol. 64, no. 5-6, pp. 999-1005, 2002.

[75] M. Barbieri, M. Bonafè, C. Franceschi, and G. Paolisso, "Insulin/ IGF-I-signaling pathway: an evolutionarily conserved mechanism of longevity from yeast to humans," American Journal of Physiology-Endocrinology and Metabolism, vol. 285, no. 5, pp. E1064-E1071, 2003.

[76] K. D. Kimura, H. A. Tissenbaum, Y. Liu, and G. Ruvkun, "Daf2 , an insulin receptor-like gene that regulates longevity and diapause in Caenorhabditis elegans," Science, vol. 277, no. 5328, pp. 942-946, 1997.

[77] R. Baumeister, E. Schaffitzel, and M. Hertweck, "Endocrine signaling in Caenorhabditis elegans controls stress response and longevity," Journal of Endocrinology, vol. 190, no. 2, pp. 191-202, 2006.

[78] C. J. Kenyon, “The genetics of ageing," Nature, vol. 464, no. 7288, pp. 504-512, 2010.

[79] C. Kenyon, J. Chang, E. Gensch, A. Rudner, and R. Tabtiang, "A C. elegans mutant that lives twice as long as wild type," Nature, vol. 366, no. 6454, pp. 461-464, 1993.

[80] J. B. Dorman, B. Albinder, T. Shroyer, and C. Kenyon, “The age1 and daf- 2 genes function in a common pathway to control the lifespan of Caenorhabditis elegans," Genetics, vol. 141, no. 4, pp. 1399-1406, 1995.

[81] I. Kawasaki, M.-H. Jeong, B.-K. Oh, and Y.-H. Shim, "Apigenin inhibits larval growth of Caenorhabditis elegans through DAF16 activation," FEBS Letters, vol. 584, no. 16, pp. 3587-3591, 2010.

[82] Y. Honda and S. Honda, "The daf-2 gene network for longevity regulates oxidative stress resistance and $\mathrm{Mn}$-superoxide dismutase gene expression in Caenorhabditis elegans," The FASEB Journal, vol. 13, no. 11, pp. 1385-1393, 1999.

[83] D. Barsyte, D. A. Lovejoy, and G. J. Lithgow, "Longevity and heavy metal resistance in daf- 2 and age-1 long-lived mutants of Caenorhabditis elegans," The FASEB Journal, vol. 15, no. 3, pp. 627-634, 2001. 
[84] C. T. Murphy, S. A. McCarroll, C. I. Bargmann et al., "Genes that act downstream of DAF-16 to influence the lifespan of Caenorhabditis elegans," Nature, vol. 424, no. 6946, pp. 277-283, 2003.

[85] K. Pietsch, N. Saul, S. C. Swain, R. Menzel, C. E. W. Steinberg, and S. R. Stürzenbaum, "Meta-analysis of global transcriptomics suggests that conserved genetic pathways are responsible for quercetin and tannic acid mediated longevity in C. elegans," Frontiers in Genetics, vol. 3, no. 48, pp. 1-11, 2012.

[86] M. Jäättelä, "Heat shock proteins as cellular lifeguards," Annals of Medicine, vol. 31, no. 4, pp. 261-271, 1999.

[87] S. L. Rea, D. Wu, J. R. Cypser, J. W. Vaupel, and T. E. Johnson, "A stress-sensitive reporter predicts longevity in isogenic populations of Caenorhabditis elegans," Nature Genetics, vol. 37, no. 8, pp. 894-898, 2005.

[88] G. A. Walker, T. M. White, G. McColl et al., "Heat shock protein accumulation is upregulated in a long-lived mutant of Caenorhabditis elegans," The Journals of Gerontology: Series A, vol. 56, no. 7, pp. B281-B287, 2001.

[89] A. R. Mendenhall, P. M. Tedesco, L. D. Taylor, A. Lowe, J. R. Cypser, and T. E. Johnson, "Expression of a single-copy hsp-16.2 reporter predicts life span," The Journals of Gerontology: Series A, vol. 67, no. 7, pp. 726-733, 2012.

[90] J. Halaschek-Wiener, J. S. Khattra, S. McKay et al., "Analysis of long-lived C. elegans daf-2 mutants using serial analysis of gene expression," Genome Research, vol. 15, no. 5, pp. 603-615, 2005.

[91] A. Strayer, Z. Wu, Y. Christen, C. D. Link, and Y. Luo, "Expression of the small heat-shock protein Hsp16-2 in Caenorhabditis elegans is suppressed by Ginkgo biloba extract EGb 761," The FASEB Journal, vol. 17, no. 15, pp. 2305-2307, 2003.

[92] J. Lund, P. Tedesco, K. Duke, J. Wang, S. K. Kim, and T. E. Johnson, "Transcriptional profile of aging in C. elegans," Current Biology, vol. 12, no. 18, pp. 1566-1573, 2002.

[93] M. Kobayashi and M. Yamamoto, "Nrf2-Keap1 regulation of cellular defense mechanisms against electrophiles and reactive oxygen species," Advances in Enzyme Regulation, vol. 46, no. 1, pp. 113-140, 2006.

[94] Y.-J. Surh, J. K. Kundu, and H.-K. Na, "Nrf2 as a master redox switch in turning on the cellular signaling involved in the induction of cytoprotective genes by some chemopreventive phytochemicals," Planta Medica, vol. 74, no. 13, pp. 1526-1539, 2008.

[95] A. Ishikado, Y. Sono, M. Matsumoto et al., "Willow bark extract increases antioxidant enzymes and reduces oxidative stress through activation of Nrf2 in vascular endothelial cells and Caenorhabditis elegans," Free Radical Biology and Medicine, vol. 65, pp. 1506-1515, 2013.

[96] N. Saul, K. Pietsch, S. R. Stürzenbaum, R. Menzel, and C. E. W. Steinberg, "Diversity of polyphenol action in Caenorhabditis elegans: between toxicity and longevity," Journal of Natural Products, vol. 74, no. 8, pp. 1713-1720, 2011. 

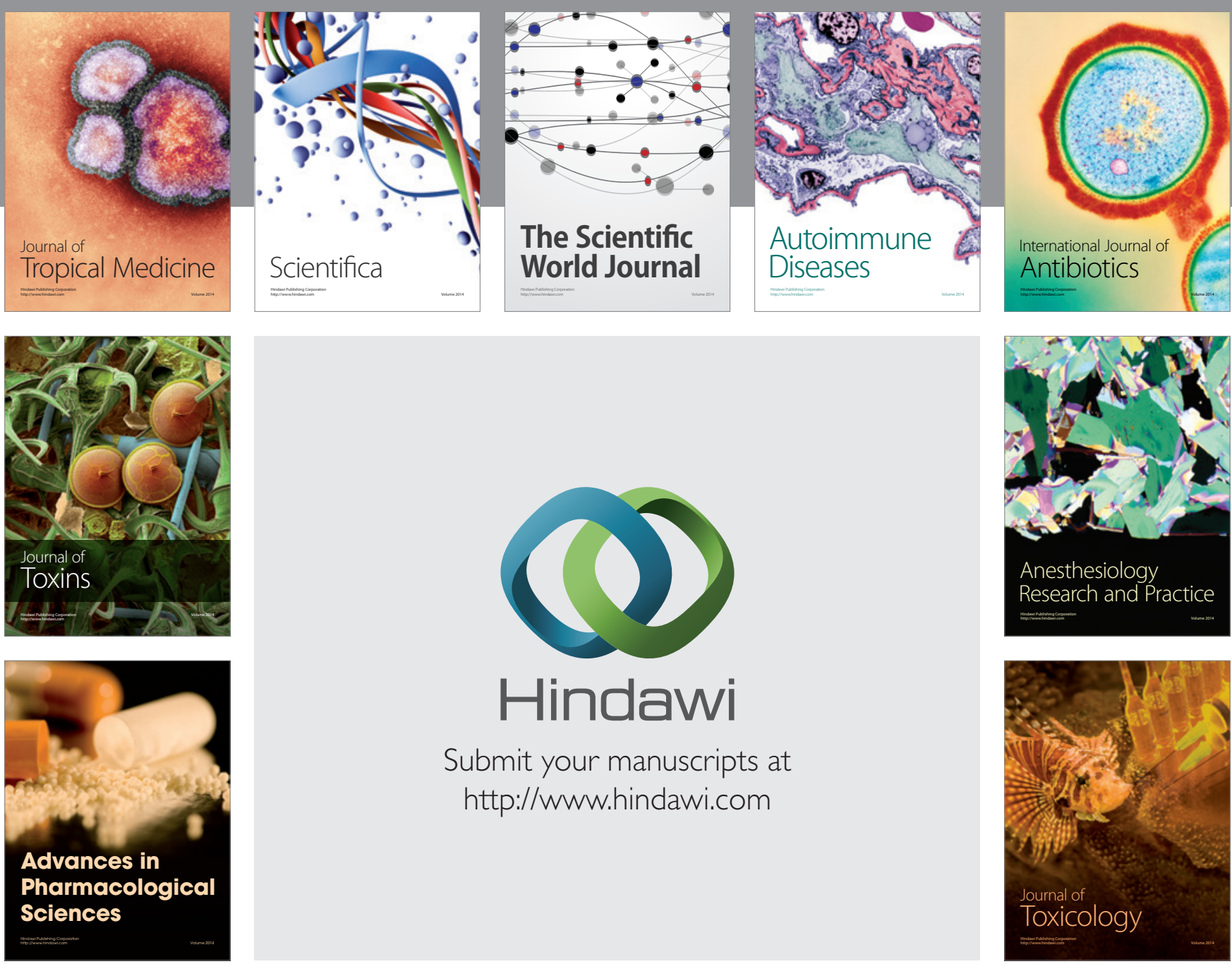

\section{Hindawi}

Submit your manuscripts at

http://www.hindawi.com
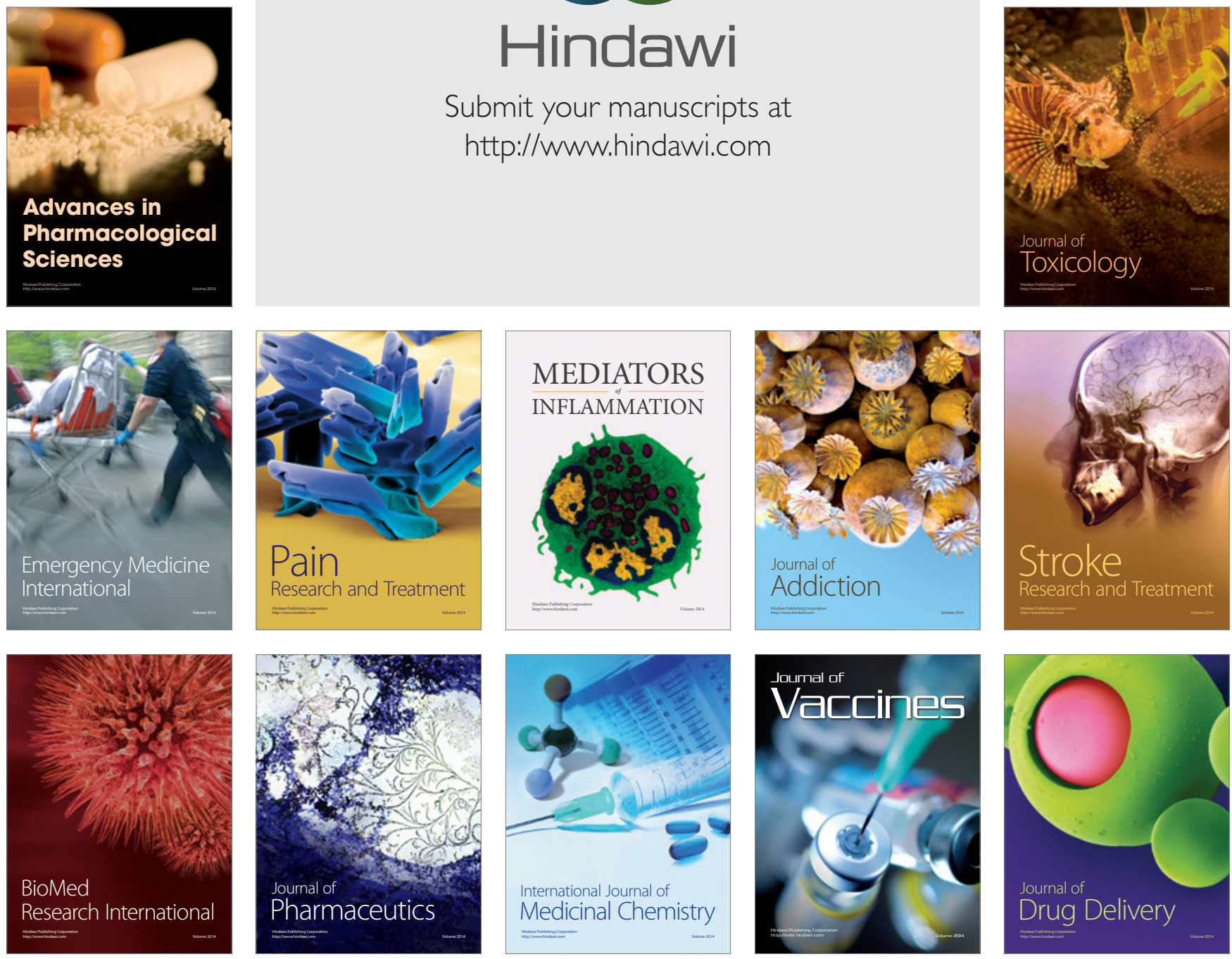